This is the post print version of the article, which has been published in Studies in Higher Education, 2019, 44 (1), 170-184.

http://dx.doi.org/10.1080/03075079.2017.1351428

This document has been downloaded from TamPub uta.fi

The Institutional Repository of University of Tampere

\title{
The Re-production Process of Gender Bias: A Case of Computer Science Professors through Recruitment in a Gender-Neutral Country
}

Tarja Tiainen and Eleni Berki, University of Tampere, Finland

Contact: tarja.tiainen@uta.fi

\begin{abstract}
Women's underrepresentation in the fields of science and technology is strong; both in software houses and academic posts. We focus on the academic field by gender sensitive analysis of computer science academics. The general picture given by statistics' meta-analyses illustrates male dominance even in Finland, which is often presented as a country which values gender equality high. For achieving deeper understanding about the process of gender bias reproduction, we focus on one university and its selection of computer science professors. Although every professorship fulfilling is a situated process, they all together shape a homogeneous male-dominant picture. This paper continues on early gender-focused discussion of Studies in Higher Education by presenting an organisational point of view.
\end{abstract}

Keywords: academic; computer science; female; gender bias; professors; recruitment policies

\section{Introduction}

Recently the journal Studies in Higher Education published the special issue Women, the Academy and the Workplace (Vol. 41, number 5, 2016) focusing on gender research. The special issue featured research on women's higher education qualifications and career progress, primarily in academy (Kearney and Lincoln 2016). The issue opened up the managerial perspective of academic work by analyzing the balance of teaching and research of male and female academic workers (Liesyte 2016) and outlined the situation of infrequent female academic leaders based on individual experiences (Read and Kehm 2016). Furthermore, the issue included several experiences from workplaces. In this paper, we continue the gender-related discussion about academic work. We focus on particular organizational processes and how the male bias among professorships is reproduced through them. In essence, this paper examines how the selection of professors occurs. We adopt a gender perspective, which reveals the mechanisms of the reproduction of the male dominance in academic posts.

Higher academic positions appear to be a male-dominated area worldwide (Tijdens and Eriksson 1991, Husu 2001a, Arruda et al. 2009). This type of gender bias in academic positions is connected to other gender biases and shaping gender ideology in the particular countries (see e.g., Göker 2005, Archibald et al. 2005). There is related comparative research even about the Scandinavian countries (e.g., Seierstad and Healy 2010), which are, often, considered as more gender-tolerance and feminine values' societies, according to the cultural diversity index of Hofstede's research (Hofstede 2001, Siakas et al. 2003).

Focussing on the recent developments of Science, Technology, Engineering and Mathematics (STEM) fields one realises that women and other minorities have been discouraged from entering STEM-related research positions and professions. Humphreys 
(1982) identified barriers for women to work participation and observes the need for intervention programmes and strategies for increasing women's participation. As the male dominance is strong in the STEM fields (e.g., Herman et al. 2013, Haas et al. 2016), we chose to study Computer Science, a discipline that is closely related to all other STEM fields. The male dominance in Computer Science has been discussed from several perspectives worldwide (see, e.g. Tijdens and Eriksson 1991, Robertson et al. 2001, Quesenberry and Trauth 2012). Besides studying the gender bias, there also exists action to change the development trend. One such example is the support to female academics by the Association for Information Systems (AIS) by formation of the AIS Women's Network (Loiacono et al. 2016). Similar initiatives have been taken by the British Computer Society and the Institute of Electrical and Electronics Engineers (IEEE).

Although Computer Science is a disciplinary field of its own, its boundaries to adjacent disciplines - Information Systems (IS), Information Technology (IT) and Information and Communication Technology (ICT) - are fuzzy. We hereby deal with them all by calling the field ICT and henceforth we use this term to refer to all the related disciplines.

\section{The Quesenberry-Trauth research framework in occupational selection}

The basis for our gender-focused study about academics in the ICT field is the research framework developed by Quesenberry and Trauth (2012). The framework's context captures occupational retention decisions for women in ICT workforce. The framework is based on career anchor theory and individual differences' theory of gender and ICT. For ICT women the most popular career anchors have been lifestyle integration (as the ability to balance their careers, family and personal growth), organisational security (e.g. job security, salary and benefits), and technical competence (opportunities to gain proficiency and build skills in technical areas). The analysis demonstrates that organisational interventions must be flexible enough to account for the diversity and variation among women.

The framework of Quesenberry and Trauth (2012) includes four contexts: individual, organisational, professional, and environmental. Of those contexts, the organisational interventions include three elements, which are (Quesenberry and Trauth 2012):

1. gender equality in the organisation,

2. targeting to the organisational level, and

3. focusing on the long-term aspects.

In addition, we utilise the Quesenberry-Trauth approach by focusing on the occupational selection from an organisation's point-of-view, considering all three organisational interventions. The case study is the reproduction of gender bias in a University's own recruitment policy. In our study we utilize the framework of Aloo et al. (2011). According to it, the main areas to look for in discrepancy in recruitment policy are (Aloo et al. 2011, p. 1008):

i) Policy plans on one hand and actual policy implementation on the other hand.

ii) Planned objectives versus actual outcomes.

iii) Differences between assumption and the reality.

iv) Discrepancy between different aspects of the policy.

In this study, we analyse the gender policies that the University uses in opening and fulfilling teaching and research positions, especially professorships. We observe the facts, which depict the assumption that gender is insignificant in recruitment processes, as well as that the outcome of the most ICT professors being male. Furthermore, we analyse the 
causes of this issue based on the recruitment situations in ICT-related posts in one Finnish University.

\section{Research Choice and Rationale}

We chose to analyse a Finnish case, since Finland is presented as a country which values gender equality (see, e.g., Ministry SAH 2014) and since there seems to exist a dilemma: promoting gender equality without a gender perspective. This means that Finland is assumed to be presented as gender-neutral but the result is a gender-blind presentation (Kuosa 2000, Saari 2013).

Another side of the gender issue is the high segregation of jobs in Finland (Kolehmainen 1999), which is seen as a low number of women in ICT professionals and academics (Vehviläinen 1996, Vehviläinen 2005, Tiainen 2006). Reasons for gender bias are also based on individual attitudes and choices and not on gender and class (Saari 2013). According to Quesenberry and Trauth (2012) this interpretation considers only the individual context and ignores the organizational, professional, and environmental contexts. This paper opens up another perspective to gender bias by focusing on organizational context by seeking an answer to the research question: How does the selection process of professors reproduce gender bias?

We start discussing the gender issues in the ICT field and then focus on the practical context of our study: gender policies and cultural issues in Finland. Metaanalyses and commentary of the statistics about gender equality in ICT academic units in Finland and references to general societal, environmental, and organisational gender issues are utilised to understand the gendered selection of the professors in the case Unit.

\section{Gender Issues in the ICT Field}

Femininity and masculinity factors appear early in the women's academic careers, and especially during and after a $\mathrm{PhD}$ degree in the ICT field. The low number of female ICT professors is a topic which is situated in cross-roads of two gender biased issues. Besides the general gender bias in higher academic positions, the masculinity of technology also provokes in personal and professional development (Grint and Gill 1995, Pulkkinen 2000). The low numbers of female ICT students (about 25 per cent of all ICT students) and female ICT professionals (around 10 to 20 per cent) are frequently researched phenomena (e.g., Camp 1997, Adam et al. 2006, Griffiths et al. 2007). This is a worldwide issue, but there are variations among countries. In Australia, for instance, successful work has been done for getting more women into the ICT field (von Hellens and Nielsen 2006, Craig et al. 2011). Research studies report that in the UK there are collaborative efforts by local councils and the British Computer Society to increase the number of girls and women in ICT studies and work in particular. Yet, women still make up smaller percentages of the tenured faculty staff than their men colleagues (Ross 2003, Black et al. 2004). University-wide there also seem to be efforts to increase the numbers of female workforce and other minorities in ICT professorships through a number of governmental and human resources regulations for equal opportunities employment (Ross 2003, Black et al. 2004).

The existing gender bias phenomenon is also known as science glass ceiling (Rosser 2004). One reason for low numbers of female professors is that for women it is more difficult to become a member of the scientific community - and that is essential for making an academic career. Female post-graduate students get less support from senior colleagues than their male counterparts (Husu 2001b). The awkwardness of the admission 
to the scientific community can also be evidenced in the low numbers of female journal editors. Their portion is only 9 per cent (Vela et al. 2012) whereas the portion of female authors is from 16 to 27 per cent (McGrath et al. 2011, Vela et al. 2012).

Besides getting access to the scientific community and feel included, there are also problems for female scientists to get admission to their home universities. In University research centres women are younger, less likely to be tenured, and at a remarkably lower rank than their male colleagues (Corley and Gaughan 2005). Female scientists discuss their research less with the colleagues in their home university than the male scientists do (Fox 2010). Frequent discussions with other faculty members about research are important because such discussions help to generate interest and support research activity. Through discussion, a scientist can evaluate problems, concepts, variables, and measures. Informal knowledge exchange also provides room for speculation, retraction, and the sharing of failures as well as successes. Since women are more marginal to the social system of communication, as indicated by the frequency of talking about research, this has consequences for their level of significant participation and status (Fox 2010).

When we try to understand gender bias in the ICT field, it is useful to start with thought-models, which include a connection between masculinity and technology. The connection is not inherent in biological sex differences, but it rather is a result of the historical and cultural construction of gender (Wajcman 1991). The background that is necessary to understand this perspective is briefly described next.

Gender symbolism means that the connection between masculinity and technology does not state that technology reflects the capacities of specific (real) men, but more probably images of hegemonic masculinities (Harding 1986, Lie 1995). Masculinity and femininity are abstract frames of reference; they are used when the description of someone's behaviour and skills is made through this frame. The connection is reproduced in everyday practices. For example, when fairly recent descriptions of men with computer were made, the frame of reference included engagement of superior knowledge and intellectual capacities as well as mastering and power that may strengthen a man's masculine image, whereas women with computing science knowledge and computer skills were connected to typewriting and office work (Lie 1995).

In all Western countries, the developers of ICT are mostly men. In fact, there are some women, as well, but they use to be invisible. For example, in Finland, at the 1970s women's share of the programmers increased to 33 per cent, and among systems designers 12 per cent, still the field was described as "worlds without women". Women did not have space in ICT pioneers' project of “national progress” (Vehviläinen 1996). In other countries and other decades similar policies and experiences are identified.

Besides open masculine bias, there is also masculinity which is hidden in gender neutrality (Saari 2013). One example of gender neutrality is the ethical and professional codes of practice created by the Association of Computing Machinery which represent a large population of North American professionals who design and build information systems. The code of practice as a whole is meant to strengthen the recognition of the professional status of computing professionals. According to Vehviläinen (1994), the first version of the code of ethics from 1972, used commonly terms that are gender neutral (e.g. member and professional), however, also "his", him" and "himself" are used. Speaking about "him" is not a coincidence but reflects the actual division of labour between sexes. It seems that women were allowed to enter the profession as long as they come as persons (not remind on their womanhood) who are willing to participate within the terms defined by the male community (Vehviläinen 1994). In this case, the situation 
has been changed later: in the newer version of code of ethics, from 1992, besides of gender neutral terms there is also used "he of she" (ACM Code 1992).

Another example of presenting world gender neutrality is elaborated by Kuosa (2000). In Kuosa's study ICT professionals described their visions of the future. On everyday talk level the visions seem gender neutral, since in the visions people are just persons, without any gender. However, the deeper analysis opens that the positive things are described in masculine world (e.g., in virtual reality everyone can be an emperor) and negative things are connected to women; for example, presenting a mother as an opposite to an ICT professional (Kuosa 2000). Also elsewhere (see, e.g., Quesenberry at al. 2006), being a mother is presented as a problem for woman in creating career in the ICT-field.

There is a long tradition for male dominance in the ICT field. Many of these biased actions have become daily practices which are not any more questioned and so they are easily renoved and constructed again. Examples of such are Trauth's paper called "odd girl out" - the name underlines female ICT professionals' problematic positions in a male's domain. The paper aims at a better understanding of the many faces of the gender gap in the ICT sector and that all of the stakeholders - governments, schools, families and employers - must examine their contribution to social shaping of the gender imbalance in the ICT professions (Trauth 2002). In a later article Trauth states that gender balance in the ICT field is needed in several reasons, which are (Trauth 2011):

(1) Innovation argument: the "best brains" can be located in a variety of bodies, not just male.

(2) Consumer argument: all citizens are engaged in the consumption of information products.

(3) Demographic argument: the desire to create a more diverse ICT labour force.

(4) Economic security argument: information sector jobs are more secure than some others; the secure jobs are not a monopoly for male.

(5) Equity argument: all people ought to have equal opportunity to pursue all careers.

Considering the previous research-based evidence of masculinity projection in the ICT field, we return to the problem area of our case: The "best brains" are needed in the scientific world to reach new understandings about the world - and information technology. If those intelligent researchers are in marginal positions, have alternative assumptions and research methods, and targeting to critical agendas, then one can reach novel knowledge (Howcroft and Trauht 2008). The objective of all scientific work is of that kind. We ponder if the selections and practices of universities target to make everything that is possible to renovate - not strengthen - the existing gender bias and those practices which construct the bias. We investigate the reproduction process through one case study of a Finnish university.

\section{Gender Bias in ICT Academic Units in Finland}

We chose to analyse a Finnish case, since Finland is largely presented as a country which values high gender equality (see, e.g., Ministry SAH 2014). The outlining of the general picture is needed as the social context with its (national and organisational) culture norms (Siakas et al. 2003) and environmental place with its predispositions' effects on individuals' actions (e.g., Harrison and Dourish 1996, Lefebvre 1998, Kaapu et al. 2013). In Finland the gender neutrality discourse is rather dominating (Siakas et al 2003), albeit many Finnish researchers have continuously revealed and reported on gender-related discrimination phenomena (Ministry SAH 2014, Equality planning 2014). The numbers 
present that women in Finland are well educated: at present, women have got 60 per cent of the Masters' degrees and 54 per cent of the PhD degrees. The fact however remains that despite higher education, women in Finland earn only 80 per cent of men's earnings (Ministry SAH 2014). The national broadcasting corporation of Finland YLE increasingly reports cases of unequal payment and retirement pensions with women earning up to 75 per cent of men's pensions. In their book on Influential Finnish Women Sievänen-Allen and Belinki (1998, p. 10) comment:

The Finnish women today have the readiness to work, help and fight as before. There is one difference, however: the goals and problems have become more global.

One explanation of the salary earnings (and later on pensions) differences is the strong segregation of the Finnish labour market (Kolehmainen 1999). Traditionally women work in health and education, whereas science and technology are male areas (Pulkkinen 2000). This dichotomy is also seen in the professors' positions: The overall total portion of female professors is only 25 per cent in all academic fields, whereas in Education 50 per cent of the professors are female, in Veterinary Medicine 52 per cent, and, finally 61 per cent of professors in health studies are female. The very opposite holds in Technology, where only 8 per cent of the professors are female, while in Natural Sciences the women's percentage is just 12 (Ministry SAH 2014). In the medicine, during last decades gender distribution has changed in all levels: for example, at 1975 only 28 per cent of medical doctors were female (Idman 2011), whereas at 201360 per cent were female (Ailasmaa 2015). Such change have not happened in the ICT field: that is male area in all levels.

In official statistics the Finnish ICT professors belong partly to the fields of Technology and partly to Natural Sciences. For this study the amount of ICT professors was calculated from the web pages of the universities at the end of 2013 and in September 2016. There were several problems in calculating the exact number of professors. The name of the ICT discipline varied among the Finnish universities; that could be Computer Science, IT, Information Systems, HCI and HTI, to name a few. Additionally, in the division to departments there were notable variations: some universities had a department just for the ICT discipline, but some others have had ICT-related degrees together with some other disciplines. In those cases, all professors' positions were double-checked in order to confirm if they were ICT-related. Some universities had a list of professors in their web page, but in some other the professors were mentioned only in the list of all staff members. The study initially aimed at taking no notice of the emeritus/emerita professors, but in some webpages there was no information on this.

The findings indicate that in the ICT field, there were 136 professors in Finland in 2013, but in the summer of 2016 the number of ICT professors was lower; only 122. In 2013 ten of the ICT professors were female, whereas only five of them were female in 2016. Thus proportionally the presence of female professors decreased from seven per cent to four per cent (Table 1).

\begin{tabular}{|l|c|c|c|}
\hline & $\begin{array}{c}\text { total } \\
\text { amount }\end{array}$ & $\begin{array}{c}\text { female amount } \\
\text { (percent) }\end{array}$ & $\begin{array}{c}\text { male amount } \\
\text { (percent) }\end{array}$ \\
\hline at the end of 2013 & 136 & $\begin{array}{c}10 \text { professors } \\
(7 \%)\end{array}$ & $\begin{array}{c}126 \text { professors } \\
(93 \%)\end{array}$ \\
\hline at the summer 2016 & 122 & $\begin{array}{c}5 \text { professors } \\
(4 \%)\end{array}$ & $\begin{array}{c}117 \text { professors } \\
(96 \%)\end{array}$ \\
\hline
\end{tabular}

Table 1. $\quad$ ICT professors in Finland at the end of 2013 and at the summer 2016. 


\section{Reshaping the Gender Bias in the Case Unit}

Although Finland is presented as a gender equal country, there seems to appear gender bias among ICT professors. Inevitably the evaluation outcomes of the Research Assessment Exercise (RAE) requiring more women staff in ICT and other disciplines push the Finnish Universities to actually implement in practice their equality plans for equal work opportunities. This is not enough; internal and external recruitment procedures also present obstacles and public advertising of posts are not, yet, open and transparent. Based on Aloo et al. (2011) we focus on the discrepancy in the recruitment policy. One part of that is policy plans and the actual policy implementation. The case Unit's university has made an equality plan. It states, for example, that it is employer's duty to act so that both women and men apply open posts. When the university finds it useful, there can be gender based special treatments in post fulfilling for decreasing gender bias. Another part of recruitment policy is the actual policy implementation.

These recruitment procedures apparently shape gender bias and this is the reason that caught our attention and motivation for the current study. The recruitment process has been observed via official university documents, which are open for everyone. Parts of the documents utilised for this research data were found from the Unit's web pages.

This study focuses only on one Unit. The case Unit offers BSc, MSc and Ph.D. programmes as in the computer science (including programming and databases), information systems, and human-computer interaction. Apparently, the Unit's current situation has been shaped so that male bias has not been given any consideration. Gender equality has not been chosen as part of a management strategy. Instead, in the light of the official discourse, the development of the unit and its personnel has been based on the needs of teaching and the competition of the different scientific disciplines. Anyhow, the case Unit seems to be as gender-biased as all other Finnish ICT units. Looking deeper into the process how male bias is reshaped in one Unit yields more general understanding of the situation in other ICT Units in Finland.

The reshaping of male bias is herein considered and observed from different perspectives. The first is the gender division of the $\mathrm{PhD}$ students as this fact gives the argument basis for hiring qualified staff members. The second one is the structure of the posts as presented, which is also structured and described by the holders' sex, especially when the focus is on the categories of professorships which are strongly male-biased. The third perspective is the hiring practices followed. This one includes the gender division of the applicants and the type of the hiring process. Describing this hiring process makes it visible how the male biased structure is shaped and also makes it possible to ponder if there is some space for making more equal opportunities policies and reaching justice.

\section{The Method of Data Gathering}

Our research uses public official documents for studying the reproduction of the gender biases in the case unit. We used two kinds of documents: the public web pages and the data of open posts. The latter revealed information about the sex-based number of applicants and the gender of the chosen one.

The data was gathered from the universities' web pages. Gathering data from the web pages was functional but it further required much work to reach meaningful information. There were no ready-made or derived statistics available of the issues which we were interested in researching. The particular gender-based statistics were missing. 
Hence, we calculated the persons from the staff member lists. The issue that made data gathering more laborious was that the staff member lists did not include the posts held by, so there was a need to reach the personal web page of every member to identify his/her post.

The second part of user materials was the post applicant information. In public organizations (e.g. universities) in Finland, the names of applicants are considered to be information of open access. The case unit's administrative staff provided us with the information of the latest years. For older data access we needed to ask the university's central administration office. When we asked, the first response that we got, was: "We need to ask the lawyer if we can give the information." For us this answer was a surprise, since we asked only to know the numbers of applicants divided to the sex, not the names of the applicants, although the latter is also assumed to be open access information. Finally we got the information - which is shown in Figure 3 in section 4.3.

\section{The Gendered Development of the PhDs}

Finland is a country with high numbers of doctoral research graduates. The report of EU Research Policies refers to Finland's research profile in comparison to other EU countries and shows doctoral graduates in Finland by gender as a ratio of the total population cohort. Female PhDs (2.8) are more than the male PhDs (2.3) and both are above the average percentage in EU countries, which are 1.4 for female and 1.6 for male, respectively (EU Research Policies 2013, page 8).

Focusing on the particular case Unit under study, the historical development of the PhDs is presented by the number of degrees divided by the holder's sex in Figure 1. In the case Unit the first PhDs graduated in 1970s. The time period in Figure 1 differentiates, and since there were a few PhDs before the time period is a decade (from 1970s to 2000) initially. As can be seen from Figure 1, after the year 2000 the number of $\mathrm{PhDs}$ increases strongly, so the time period is divided to five years.

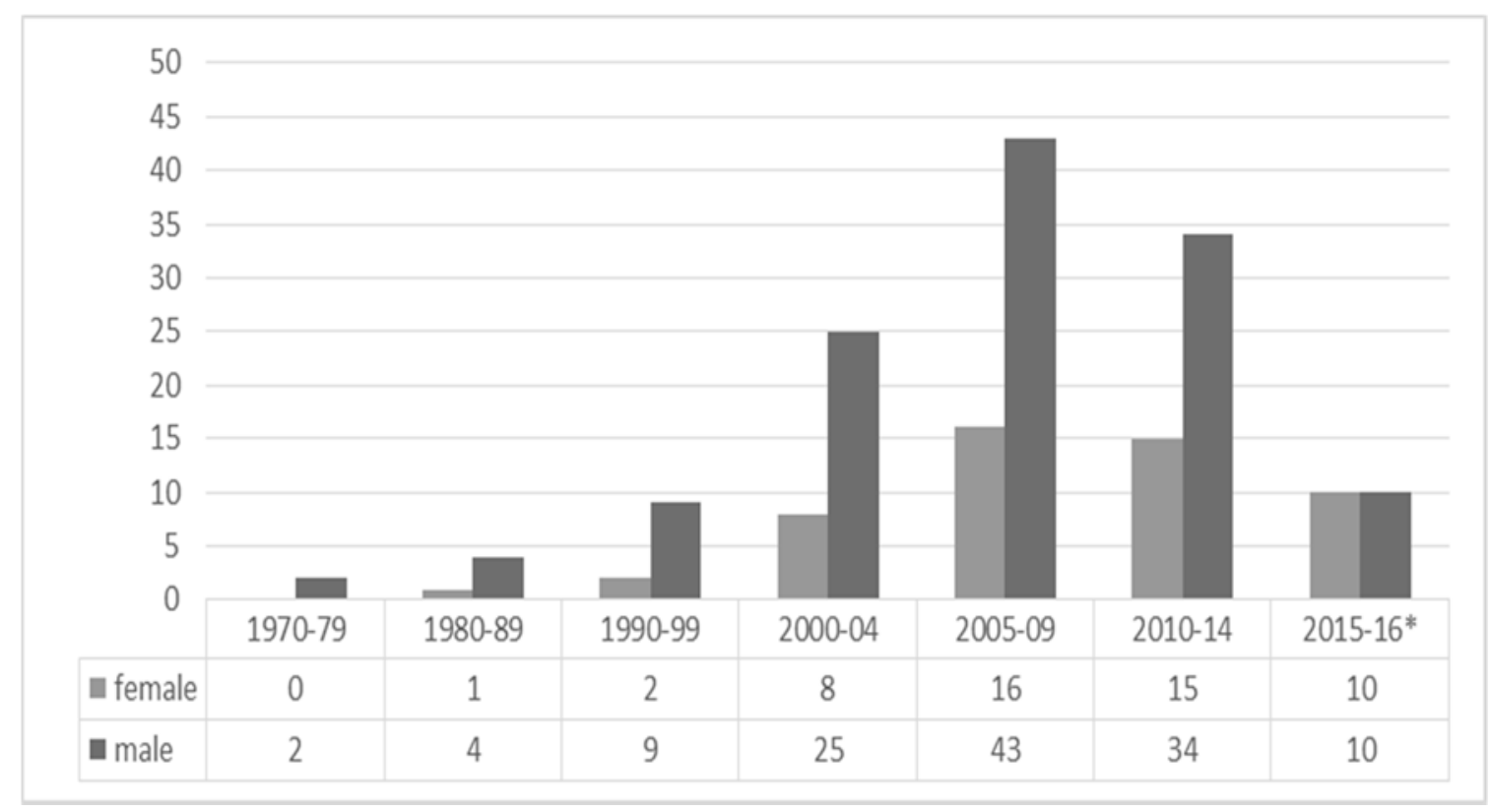

Figure 1. The numbers of Ph.Ds. at the case School; presented based on the gender and by the total number of the end of time period. Notice: the last period (2015-16) is only two years. 
The total number of $\mathrm{PhDs}$ is 179; there are 127 male $\mathrm{PhDs}$ and 52 female ones. The portion of women with $\mathrm{PhDs}$ is being increased. Notably, before 2000 it is 18 per cent, at the end of 2004 it is 24 per cent and at 2016 the female perception of all PhDs awarded in the Unit is 29.

The PhD numbers are far away from gender equality. However, when the gender based numbers of PhDs are compared to the numbers of female master students, the bias is not that bad. During the last decades, the portion of female master students in the case Unit has varied between 15 to 25 per cent. The numbers are similar to those elsewhere in the rest of Finland and in other countries (von Hellens and Nielsen 2001, Miliszewska 2006, Zweben 2010, Naisia 2011).

\section{The Gendered Structure of the Unit's Staff}

The Unit's teaching personnel includes six professors and twelve instructors, as presented in Figure 2. The Unit's professors are either with permanent or temporary work contract. A permanent professor is the same as a full professor. Their qualifications are evaluated and they have the position until their retirement. Their work duties comprise teaching, supervising, researching (including applying for research funding) and administration. The reason for a temporary professorship is the need to have a substitute of a full professor, who has accepted a temporary job elsewhere. Another reason for a temporary professorship is temporary funding from outside the University. The fixed time for a temporary professor's position can be 1-5 years.

The other kind of teaching personnel is, herein, called instructor. This title includes two kinds of posts: first, lecturers which are teaching-focused positions, and second, assistant professors which are almost half-research and half-teaching positions. Lecturers' positions are supposed to be permanent posts, but they can also be substitute posts. Assistant professors are temporary posts, mostly for five years, but sometimes for two or three years. They are, sometimes, considered as post-doc positions for becoming qualified enough for a future (associate) professorship.

Figure 2 illustrates the changes in the previously described posts during the last twelve years. The first change, in the instructor level, indicates that the number of instructors is decreased from 15 to 13. At the same level, the structure of instructors' post changes: the development trend has been placed from temporary, research-oriented posts to permanent teaching-oriented posts. At 2004 there were three permanent instructor posts, whereas at 2016 there were nine of them. At the same time the number of temporary posts has been decreased from twelve to four. The staff members prefer permanent posts and the Finnish law system also demands permanent posts when there are no special reasons. However, as permanent staff members are mostly employed as lecturers, the time for doing research is minimal.

The second change in the Unit's staff is that both the number and portion of women have slightly been increased. The total portion of female staff members has been increased from 20 per cent to 37 per cent. Among the different post levels the change has happened in the permanent instructors: in 2004 there was only one, whereas in 2016 there were five. At the same time the number of male temporary instructors has decreased from ten to two.

The third change is a decrease in the number of professors. The number of the Unit's permanent professors has decreased from seven to five. They all are and have been male. In 2004 there were two temporary female professors and a male one. Twelve years afterwards, in 2016, there were only one male temporary professor and no female. Hence, the structure of the teaching personnel of the case Unit predetermines that women end up 
becoming lecturers whereas men end up becoming professors. The fact that women become lecturers complicates women's careers more, due to the increased and evergrowing teaching overload; thus, the road towards a professorship becomes more difficult, without time to dedicate to research. Nonetheless the expectations from women in instructors/teaching jobs in academy are demanding. Research studies in other countries present that female lecturers are expected to guide and help students much more than their male colleagues (Bennett 1982, Basow and Silberg 1987). In the case Unit, the men normally end up to research-oriented post-doc posts; so they have had better chances for research and publishing, which are the main criteria for getting promoted.

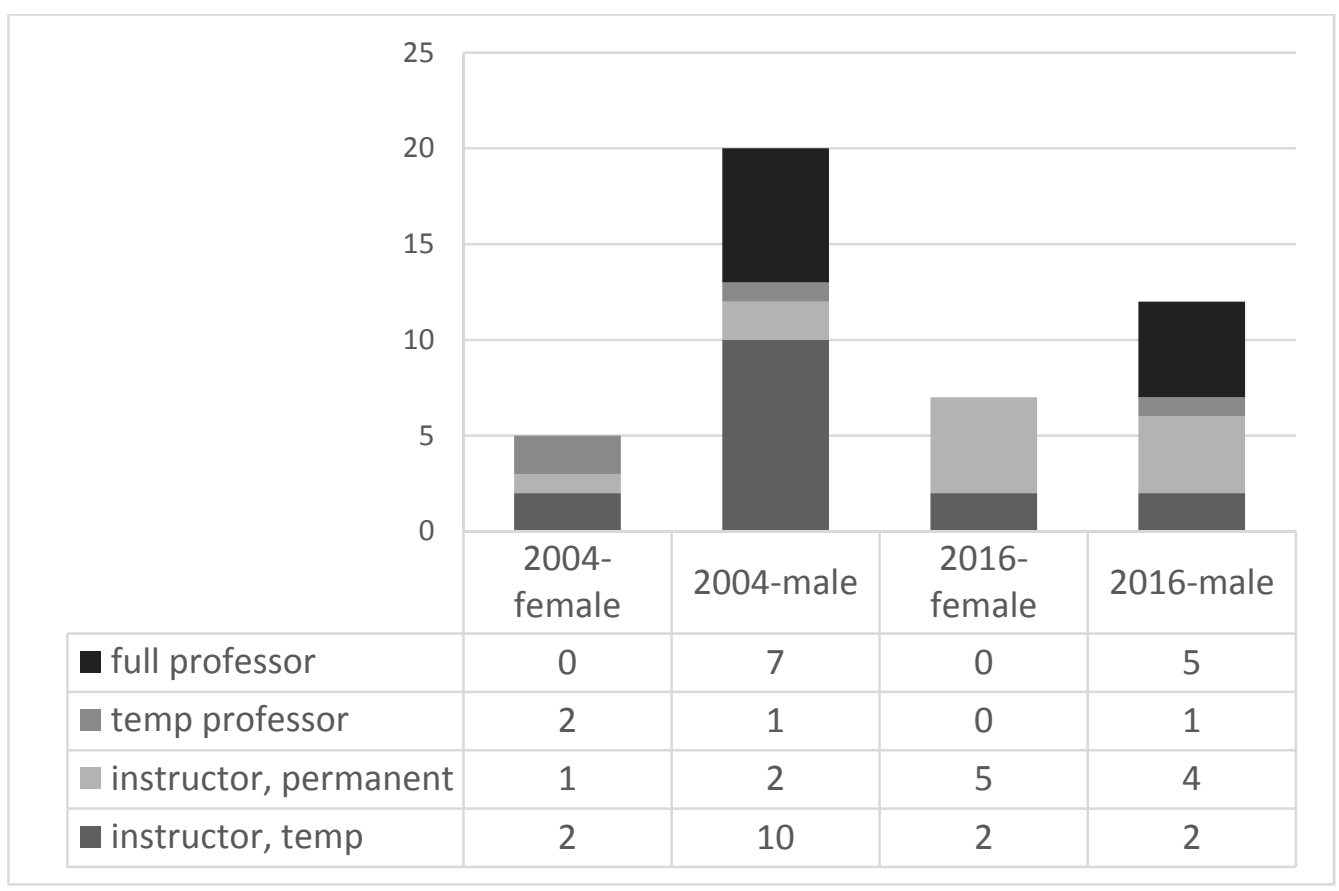

Figure 2. The case School's gender divided numbers of teaching staff at 2004 (Tiainen 2006) and at 2016 (taken from the case School's web page).

\section{The Fulfilling of ICT Professorships - Change and Status Quo}

In Finnish Universities the typical way to fulfil the full professorships is through open call for anyone to apply, whereas the short term professorships are fulfilled by the decision of the Unit's Dean and confirmed by the University's Rector. A short term professorship has a maximum length of two years; so longer temporary professorships are, normally, open for anyone to apply. The University also recommends using this policy in fulfilling full professorships.

The case Unit's procedures and policies of fulfilling the professorships are hereby scrutinised from a wider perspective, which allows us to further identify gender-bias reasons that hinder women from academic ICT higher positions. The particular procedures for fulfilling higher positions are described and analysed based on the University's official documents. We focus on the position recruitment and fulfilment process during the last 15 years.

During the 21st century there were five open calls for full professorships, all during 2001-05 (Figure 3). In every single case a man was chosen. Furthermore, three men were invited to permanent professorships. They were invited between 2006 and 2015. None of the women were chosen or invited to a permanent professorship. 


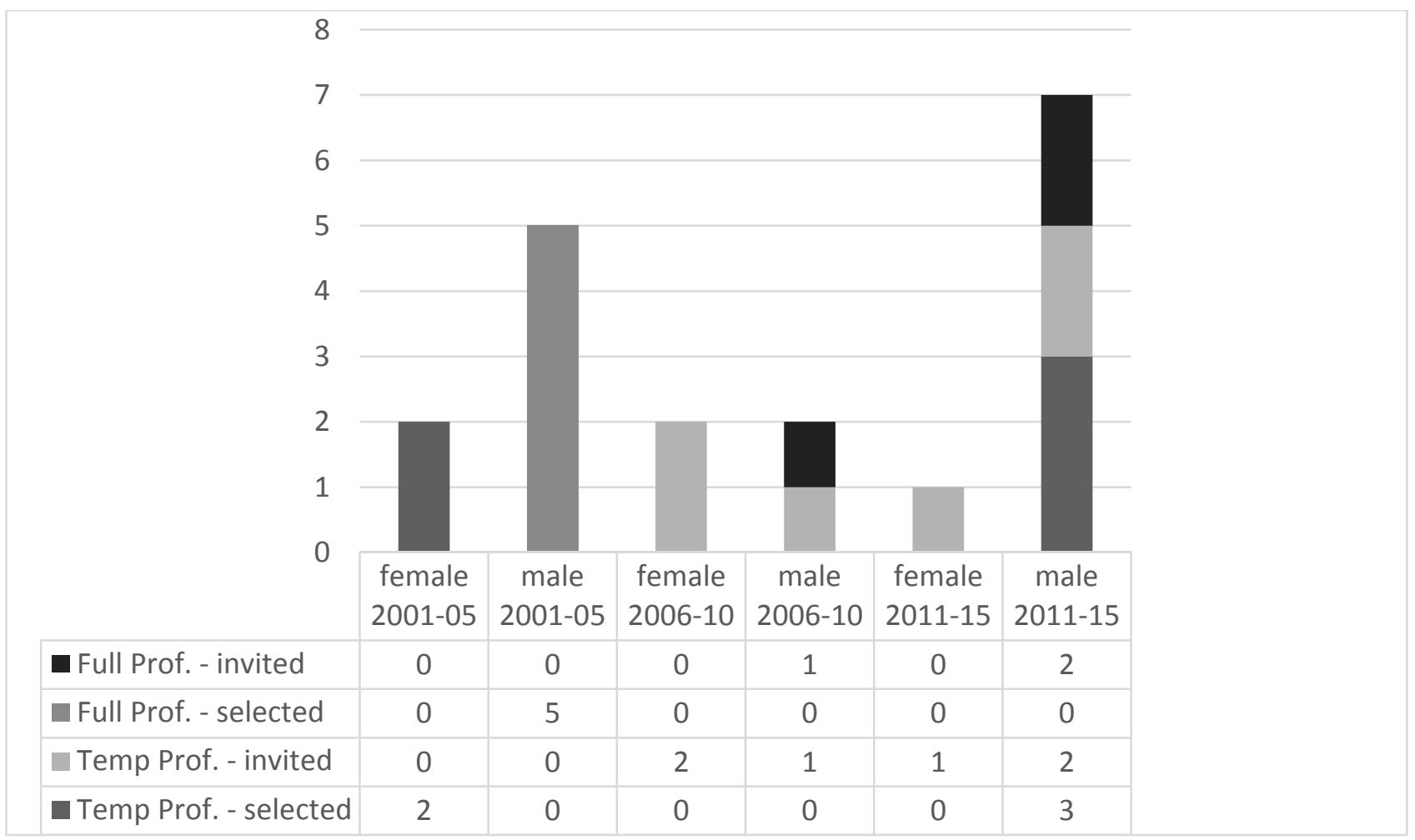

Figure 3. Fulfilling the professorships in the case School. The numbers are presented by five year periods separate by the gender (first female ones and then male ones).

Temporary professorships have also been fulfilled during the period of 15 years. Based on open call two women were selected to temporal professorships at the period 2001-05 and three men were selected at the period 2010-15. Figure 3 shows that three women were invited to temporary professorships. In fact, in all these cases the same woman got a short period post, several times. Moreover, three men were invited to temporary professorships - and they were, actually, three different men.

There were female applicants in all open calls, but none of them was chosen. The usual general statement for justifying the absence of female ICT professors has been that there were no qualified candidates. The actual reasons for not selecting any of the female applicants could be explained from several perspectives, which we discuss next.

One issue raised herein is why the female applicants were not evaluated as the best ones. The evaluation of the applicants was carried out by other scientists. It has been justified why the evaluation is neither objective nor gender neutral (Steinpreis et al. 1999). This has been researched by giving the same curricula vitae with two alternative names (a male one as "Brian Miller" and a female one as "Karen Miller") for reviewers to decide if the candidate had been qualified enough. The male applicant was evaluated as more qualified (Steinpreis et al. 1999). The official job application documents do not certainly include information about possible gender bias in the job applicants' evaluation. However, that possibility needs to be kept in mind.

The second issue is the change of professorship fulfilling policy, which is another critical issue in recruitment and organisational development. Henceforth, we focus more on those who have got full professorship by invitation. All of them had worked in the case Unit before the invitation to apply for the post: two of them were temporary professors and one in a temporary research position. One woman, who had a temporary professorship, got another temporary professorship by invitation. When a professorship 
is fulfilled by invitation, it is significant which position the candidate has in the Unit's scientific community. Other studies state that women' role is minor in scientific community (Fox 2010, McGrath et al. 2011, Vela et al. 2012). In such recruitment situations women are, apparently, underestimated and ignored for promotion to full professors.

The third issue is that the fulfilling policy has changed. The first change happened in 2005. That was the time when there were several female PhDs who could have been potential applicants for the posts. After 2005 there have been no open calls for permanent professorships. The other change happened in 2010, stating that professors should be selected with tenure track in mind which starts with a five-year temporary post. Meanwhile the value of internationalism increased, so the open calls had to be internationalised in order to attract potential international staff. The number of applications has been expanded - from three to ten earlier to 50 or more applications. However, international applicants also include both male and female candidates for the positions.

\section{Conclusions and Critical Overview}

Women's absence among ICT professors in many countries is a world-wide phenomenon. The commonness of gender bias is certainly not making it acceptable. We observed the phenomenon by focusing on one case Unit and observing its gender compared statistics of PhDs, staff members, and fulfilling of professorships. These, sadly, outline a gender biased picture. The statistics comparison revealed that women's portion in female $\mathrm{PhDs}$ has been increased in the last 15 years from 24 per cent to 29 per cent and in lecturers' positions from 33 per cent to 55 per cent; but notably decreased in professors' positions from 22 per cent to zero.

Data gathering for our study was more difficult than expected. There were a few gender-based statistics available, although in Finland it is expected to make organizational equality plans when there is some gender bias in the organization (Equality planning 2014). The University has made an equality plan as it is expected. Still, however, there has been a limited number of gender-based statistics. The shortage of statistics is in line with Saari's statement that Finland is gender-blind, not gender-neutral (Saari 2013).

The reasons for gender bias can also be sought from female PhDs own choices; they use to value the stability offered by permanent posts higher than the short-term benefits from provisional and non-permanent ones (Quesenberry and Trauth 2012). Consequently, that way of thinking values the position of a permanent lecturer higher (although it does not include time for research, which is needed for becoming qualified for a professorship) than the position of a temporary associate professor. The reasons can also be sought from the case Unit's practices, as evidenced in the professorship fulfilling process. In that, two controversial for their fairness and transparency mechanisms have been used: First, the case Unit often invites and employs new professors, although that is not a preferred way of recruitment in the University. For getting that kind of post, someone demands a high position in the local (academic) community - and that is more difficult for women than men. The second mechanism is the so-called open call. This gives a possibility for more to apply. However, in the evaluation process when the evaluators know the gender of the applicants, male applicants might be valued higher than female one with similar CVs, as Steinpreis et al. (1999) prove in their empirical study. This bias is based on the predisposition which connects masculinity to technology and 
professionalism, and that strengthens the evaluators' impression of male candidates' competence (e.g., Lie 1995, Steinpreis et al. 1999).

The gender bias in the ICT field has been under discussion for decades (e.g., FoxKeller 1985, Harding 1986, Camp 1997, Adam et al. 2004). There has been clear statistical evidence that female $\mathrm{PhDs}$ become permanent lecturers, whereas male $\mathrm{PhDs}$ might become professors. Besides the gender bias result we also described the process of re-shaping the gender bias; that had to do with the practices in the fulfilling of the professorships in the case Unit. The reasons for the science glass ceiling (concept from Rosser 2004) existence in the case Unit can further be traced back to hidden gender-bias and scientific bias in organisational policies.

The framework of Quesenberry and Trauth (2012), which structures the occupational retention decisions for women in the ICT workforce, was utilised in our study. One part of the framework is organisational context, in which interventions include the items of 1 . gender equality in the organisation, 2. targeting the organisational level, and 3. focusing on the long-term aspects. The analysis of the case Unit outlines that there is no gender equality; for example, the statistics of $\mathrm{PhDs}$ and staff members in different kind of posts state the obvious biases. So the first item gets a negative result. Instead, the third item gets positive results in the case Unit: women end up to permanent posts by becoming lecturers.

Many studies underline the importance of mentoring (Devos 2004, Berki 2006, de Cheveigne 2009), especially for women. The absence of women in higher academic positions affects the mentoring of female academic staff. There is a need for mentoring young women (Grodzinsky and Gumbus 2005) by other experienced and advanced in their career women (but not necessarily men) with wisdom in order to buffer the effect of negative climate (Settles et al. 2007) and safeguard women's work-life balance (Berki and Cobb-Payton 2005).

One study area of women and ICT is the females' perspective as the decisions of the work area affect personal and professional life; this has been structured and paid attention to by Quesenberry and Trauth in their framework (2012). Another focus is on the reasons why gender equality needs to be strengthen, pointed by Trauth (2011). One reason that also fits well to the academic discourse is the innovation argument, which states that the "best brains" can be located in a variety of bodies, not just male.

In the case Unit, there were eight open calls at the studied time period. To all of them were both female and male applicants, but in all cases a male was chosen. That is argued by supporting that the best applicants were chosen. However, the study of Steinpreis et al. (1999) brings doubt to the particular argument, as it states that when the same application is sent with male and female name, the male one is valued as more qualified. Notwithstanding the differences in evaluation of male and female candidates are connected to gender symbolism which connects masculinity and technology (Harding 1986, Lie 1995). It is not possible to say in one way or another: 'it can be the best applicant who was selected or the best one might be bypassed'. In the case Unit, eight men were selected since they were evaluated as the best candidates for the posts. It is impossible to prove if they were the best ones, since masculinity gives extra value to candidates. For alleviating the produced gender bias active actions for promoting female candidates are needed, and perhaps recruitment strategies like equal opportunities and positive discrimination should be considered as standard organisational policies. These have been applied successfully in similar cases elsewhere. 


\section{References}

ACM Code, 1992. ACM Code of Ethics and Professional Conduct. http://ethics.acm.org/code-of-ethics [obtained 1.6.2017]

Adam, A., D. Howcroft, and H. Richardson. 2004. "A decade of neglect: reflecting on gender and IS”. New Technology, Work and Employment 19 (3): 222-240.

Adam, A., M. Griffiths, C. Keogh, K. Moore, H. Richardson, and A. Tattersall. 2006. "Being an 'it' in IT: gendered identities in IT work." European Journal of Information Systems 15: 368-378.

Ailasmaa, R. 2015. Terveys- ja sosiaalipalvelujen henkilöstö 2013. Tilastoraportti 26/2015, 10.12.2015. Tilastokeskus.

Aloo, J. O., E. M. W. Simatwa, and R. A. Nyang'ori. 2011. “Impact of the School Based Teacher Recruitment Policy on the Distribution and Retention of Teachers in Public Secondary Schools in Kenya: A case study of Nyando District.” Educational Research 2(3): 1006-1020.

Archibald, J., J. Emms, F. Grundy, J. Payne, and E. Turner, eds. 2005. The Gender Politics of ICT. Middlesex University Press: Enfield, Middlesex.

Arruda, D., F. Bezerra, V. A. Neris, P. Rocha, and J. Wainera 2009. "Brazilian computer science research: Gender and regional distributions.” Scientometrics 79 (3): 651665.

Basow, S. A. and N. T. Silberg 1987. "Student evaluations of college professors: Are female and male professors rated differently?” Journal of Educational Psychology 79 (3): 308-314.

Bennett, S. K. 1982. "Student perceptions of and expectations for male and female instructors: Evidence relating to the question of gender bias in teaching evaluation.” Journal of Educational Psychology 74 (2): 170-179.

Berki, E. 2006. "Mentoring as a Learning Process - relationships and communication." Investigations in University Teaching and Learning 3 (1), London Metropolitan University Press: London, 42-49.

Berki, E. and F. Cobb-Payton. 2005. "Work-Life Balance and Identity in a Virtual World: Facts, Tensions and Intentions for Women in IT.” In Lost and Found in Virtual Reality: Women and Information Technology. edited by $\mathrm{H}$. Isomäki and A. Pohjola. 275-296. University of Lapland Press: Rovaniemi.,

Black, S., C. Boldyreff, F. Paterson, and M. Ross. 2004. "Web-based Communities for girls and women in IT: Countering influences from home, school, and work through to retirement." In the Conference Proceedings of P. Isaias and P. Commers (Eds), 1st IADIS Conference on Web-based Communities, Mar 24-26, Lisbon, 477-481.

Camp, T. 1997. “The Incredible Shrinking Pipeline.” Communications of the ACM 40 (10): 103-110.

de Cheveigne, S. 2009. "The Career Paths of Women (and Men) in French Research.” Social Studies of Science 39 (1): 113-136.

Corley, E. and M. Gaughan. 2005. "Scientists" Participation in University Research Centers: What are the Gender Differences?” Journal of Technology Transfer 30: 371-381.

Craig, A., J. Fisher, and L. Dawson. 2011. "Women in ICT; guidelines of evaluating intervention programmes.” ECIS 2011: European Conference on Information Systems, Finland: Aalto University, pp. 1-13. 
Devos, A. 2004. "The project of self, the project of others: mentoring, women and the fashioning of the academic subject.” Studies in Continuing Education 26 (1): 6780.

Donovan, C., B. Hodgson, E. Scanlon, and E. Whitelegg. 2005. "Women in higher education: Issues and challenges for part-time scientists." Women's Studies International Forum 28 (2-3): 247-258.

Equality planning (2014). "General information on equality planning." The Office of the Ombudsman for Equality.

http://www.tasa-arvo.fi/en/promoting_equality/workplace/planning [obtained 26.11.2014].

Fox, M. F. 2010. "Women and Men Faculty in Academic Science and Engineering: Social-Organizational Indicators and Implications." American Behavioral Scientist 53 (7): 997-1012.

Fox-Keller, E. 1985. Reflections on Gender and Science. Yale University Press: Yale.

Griffiths, M., K. Moore, and H. Richardson. 2007. "Celebrating Heterogeneity? A survey of female ICT professionals in England. ” Information, Communication \& Society 10 (3): 338-357.

Grint, K. and R. Gill. 1995. The Gender-Technology Relation, Contemporary Theory and Research. Taylor \& Francis.

Göker, G. 2005. “Gender in Advertisements of Information Technologies.” In Lost and Found in Virtual Reality: Women and Information Technology. edited by $\mathrm{H}$. Isomäki and A. Pohjola, 239-274. University of Lapland Press: Rovaniemi,

Grodzinsky, F. S. and A. Gumbus. 2005. "Networking and Career Advancement Strategies for Women: A study of the effects of networking and mentoring on ICT careers for women.” In The Gender Politics of ICT. edited by J. Archibald, J. Emms, F. Grundy, J. Payne, and E. Turner, 297-311. Middlesex University Press: Enfield, Middlesex.

Haas, M., S. T. Koeszegi, and F. Zedlacher. 2016. "Breaking Patterns? How Female Scientists Negotiate their Token Role in their Life Stories.” Gender, Work and Organization 23 (4): 397-413.

Harding, S. 1986. The Science Question in Feminism. New York: Cornell University Press.

Harrison, S. and P. Dourish. 1996. "Re-Place-ing Space: the roles of place and space in collaborative systems.” In CSCW 1996, Proceedings of the 1996 ACM conference on Computer supported cooperative work, ACM, New York, pp. 67-76.

von Hellens. L. and S. Nielsen. 2001. "Australian Women in IT.” Communications of the ACM 44 (7): 46-52.

von Hellens, L. and S. Nielsen. 2006. "Facing and Changing Reality in the Australian IT Industry." in Encyclopaedia of Gender and Information Technology, edited by E. Trauth, Hershey, Idea Group Reference.

Herman, C., S. Lewis, and A. L. Humbert. 2013. "Women Scientists and Engineers in European Companies: Putting Motherhood under the Microscope.” Gender, Work and Organization. 20 (5): 467-478.

Hofstede, G. 2001. Culture's Consequences: comparing values, behaviors, institutions, and organizations across nations (2nd ed.). Thousand Oaks, CA: SAGE Publications.

Howcroft, D. and E. M. Trauth. 2008. "The implication of a critical agenda in gender and IS research” Information Systems Journal 18: 185-202.

Humphreys, S. M. 1982. "Women and Minorities in Science. Strategies for Increasing Participation.” AAAS Selected Symposium 66, Westview Press, Inc. Coloranto. 
Husu, L. 2001a "On metaphors on the position of women in academia and science." NORA - Nordic Journal of Feminist and Gender Research 9 (1): 172-181.

Husu, L. 2001b. Sexism, Support and Survival in Academia. Academic Women and Hidden Discrimination in Finland, University of Helsinki, Finland.

Idman, M. 2011. "Naiset aiempaa vaativammissa tehtävissä - palkkapussi ennallaan.” Tieto\&trendit 6/2011.

Kaapu, T., T. Tiainen, and A. Ellman. 2013. "User Interpretations of Virtual Prototypes: Physical Place Matters.” Scandinavian Journal of Information Systems 25 (2): 83104

Kearney, M.-L. and D. Lincoln. 2016. "Foreword: Gender research: women, the academy and the workplace.” Studies in Higher Education 41 (5): 799-800.

Kolehmainen, S. 1999. Women's and Men's Work: Labour Market Segregation in Finland 1970-1990. University of Tampere, Finland. Tilastokeskus, tutkimuksia 227.

Kuosa, T. 2000. “Masculine World Disquised as Gender Neutral.” In Women, Work and Computerization, edited by E. Balka and R. Smith, 119-126. Kluwer Academic Publishers, Boston, USA.

Lefebvre, H. 1998. The Production of Space, Blackwell, Oxford.

Leisyte, L. 2016. New public management and research productivity - a precarious state of affairs of academic work in the Netherlands. Studies in Higher Education 41 (5): 828-846.

Lie, M. 1995. “Technology and Masculinity: The Case of Computer.” The European Journal of Women's Studies 2 (3): 379-394.

Loiacono, E., L. S. Iyer, D. J. Armstrong, J. Beekhuyzen, and A. Craig. 2016. "AIS Women's Network: Advancing Women in IS Academia," Communications of the AIS, 38, Article 38. Available at: http://aisel.aisnet.org/cais/vol38/iss1/38

McGrath, C. J., S. Nigai, and J. Kaye. 2011. "Gender and Computing Conference Papers.” Communications of the ACM 54 (8): 72-80.

Miliszewska, I. 2006.” Gender Bias in Computer Courses in Australia.” In Encyclopedia of Gender and Information Technology, edited by E. M. Trauth, 501-512. Idea Group Reference, London, UK.

Ministry SAH. 2014. Ministry of Social Affairs and Health, Finland. www.stm.fi/en/gender_equality [obtained at 1.2.2014].

Naisia. 2011. Naisia ICT-alalle! -tutkimus. (Women to the ICT field - a study). Teknologiateollisuus ry. SP-Paino Oy, Nurmijärvi.

Pulkkinen, L. 2000. "Life-Span Perspective on Human Centred Technology.” (Keynote Speech). At Eurovillage, Brussels, 30.5.2000.

Quesenberry, J. L. and E. M. Trauth. 2012. "The (dis)placement of women in the IT workforce: an investigation of individual career values and organizational interventions.” Information Systems Journal 22:457-473.

Quesenberry, J. L., E. M. Trauth, and J. A. Morgan. 2006. "Understanding the "Mommy Tracks": A Framework for Analyzing Work-Family Balance in the IT Workforce.” Information Resources Management Journal 19(2): 37-53.

Read, B. and B. M. Kehm.2016. "Women as leaders of higher education institutions: a British-German comparison.” Studies in Higher Education 41 (5): 815-827, DOI: 10.1080/03075079.2016.1147727

Robertson, M., S. Newell, J. Swan, L. Mathiassen, and G. Bjerknes 2001. "The issue of gender within computing: reflections from the UK and Scandinavia.” Information Systems Journal 11 (2): 111-126. 
Ross, M. 2003. “Girls into IT and Technology.” IEE Engineering Education, Southampton, UK.

Rosser, S. V. 2004. “The Science Glass Ceiling.” Press Release, 16.2.2004. The Georgia Institute of Technology.

Saari, M. 2013. "Promoting Gender Equality without a Gender Perspective: Problem Representations of Equal Pay in Finland.” Gender, Work and Organization 20 (1): 36-55.

Seierstad, C. and G. Healy. 2012. "Women's equality in the Scandinavian academy: a distant dream?” Work, employment and society 26 (2): 296-313.

Siakas, K., E. Berki, and E. Georgiadou. 2003. "SQM CODE: Cultural and Organisational Diversity Evaluation for Software Quality Management.” In The Proceedings of EuroSPI 2003 (European Software Process Improvement), edited by Messnarz, 31-45. Graz, Dec. 10-12.

Sievänen-Allen, R. and K. Belinki. 1998. Suomalaisia Vaikuttaja-Naisia. Kohti Vuotta 2000. (Influential Finnish Women. Towards 2000). WSOY: Juva.

Steinpreis, R. E., K. A. Anders, and D. Ritzke. 1999. "The Impact of Gender on the Review of the Curricula Vitae of Job Applications and Tenure Candidates.” Sex Roles 41 (7/8), 509-528.

Tiainen, T. (2006). “Constructing Gender Bias in Computer Science.” in Encyclopedia of Gender and Information Technology, edited by E. M. Trauth, Idea Group Reference, London, UK. pp. 135-140.

Tijdens, K. and I. Eriksson. 1991. "Report of the Conference.” In Women, Work and Computerisation: Understanding and Overcoming Bias in Work and Education. edited by I. V. Eriksson, B. A. Kitchenham, and K. G. Tijdens. 11-12. Helsinki, Finland, Jun 30 - Jul 2. Elsevier Publishers: Amsterdam.

Trauth, E. M. 2002,"Odd girl out: an individual differences perspective on women in the IT profession", Information Technology \& People 15 (2): 98-118. doi:

http://dx.doi.org/10.1108/09593840210430552

Trauth, E. 2011. "What Can We Learn from Gender Research? Seven Lessons for Business Research Methods." The Electronic Journal of Business Research Methods 9 (1): 1-9.

Vehviläinen, M. 1994. "Reading Computing Professionals' Codes of Ethics - A Standpoint of Finnish Office Workers." In Feminist Voices on Gender, Technology and Ethics. edited by E. Gunnarsson and L. Trojer. 145-161. Luleå University of Technology, Luleå, Sweden.

Vehviläinen, M. 1996. "Maailmoista ilman naisia tietotekniikan sukupuolieroihin.” In Työelämän sukupuolistavat käytännöt, edited by M. Kinnunen and P. Korvajärvi. 143-170. Vastapaino, Tampere, Finland.

Vehvilainen, M. 2005. "The Numbers of Women in ICT and Cyborg Narratives: On the Approaches of Researching Gender in Information and Communication Technology." In Lost and Found in Virtual Reality: Women and Information Technology. edited by H. Isomäki and A. Pohjola. 23-46. University of Lapland Press: Rovaniemi.

Vela, B., P. Cáceres, and J. M. Cavero. 2012. "Participation of women in software engineering publications.” Scientometrics 93 (3): 661-679.

Wajcman, J. 1991. Feminism Confronts Technology, Cambridge, UK: Polity Press.

Zweben, S. 2010. "Computing Degree and Enrolment Trends.” Computing Research Association. 2010-11. Washington, DC. 